\author{
Chirurgia (2021) 116: 143-149 \\ No. 2, March - April \\ Copyright@ Celsius \\ http://dx.doi.org/10.21614/chirurgia.116.2.143
}

\title{
Surgical Management of the Breast and Axilla after Neoadjuvant Therapy
}

\section{Dan Hershko*}

Department of Surgery A, Emek Medical Center, Afula, Israel

${ }^{*}$ Corresponding author:

Dan Hershko, M.D

Professor of Surgery

Chief, Department of Surgery

Emek Medical Center, Afula, Israel

E-mail: dan_he@clalit.org.il

\section{Rezumat \\ Tratamentul chirurgical al sânului și al axilei după terapia neoadjuvantă}

Indicatiile privind utilizarea chimioterapiei neoadjuvante (NAC) pentru gestionarea cancerului de sân s-au extins foarte mult în ultimii ani. Destinată inițial pentru cancerul de sân inoperabil, această modalitate a devenit apoi standardul de îngrijire pentru cancerele avansate local. Acest tratament a permis efectuarea rezecțiilor chirurgicale cu margini de siguranță şi, în cazul multor pacienți cu tumori voluminoase, a permis intervenția chirurgicală de conservare a sânilor, cu evitarea mastectomiei. Pe măsură ce experiența clinică cu NAC a crescut odată cu introducerea de medicamente noi şi cu o mai bună înțelegere a biologiei tumorale, indicațile pentru utilizarea sa au devenit şi mai frecvente pentru tratamentul unor subtipuri de cancer mamar incipient. Mai mult, s-a constatat că utilizarea NAC determină scăderea necesității disecției ganglionare axilare la pacienți selectați ce prezintă inițial ganglioni limfatici pozitivi. Acest articol va analiza practica actuală şi indicațiile NAC în cancerul de sân, precum şi unele probleme controversate cu privire la tratamentul chirurgical al sânului şi al axilei în urma tratamentului neoadjuvant.

Cuvinte cheie: cancer de sân, chimioterapie neoadjuvantă, intervenție chirurgicală de conservare a sânului, nodul santinelă, tratament biologic

\section{Abstract}

The indications for the use of neoadjuvant chemotherapy (NAC) 
for the management of breast cancer have broadened immensely in recent years. Initially intended mostly for inoperable breast cancers, this modality has then became the standard of care for locally advanced cancers. This treatment allowed safe surgical margin resection and in many patients with large tumors it allowed breast conserving surgery, avoiding the need for mastectomy. As clinical experience with NAC has increased along with the introduction of novel medications and better understanding of tumor biology, the indications for its use have become even more common for the treatment of some subtypes of early breast cancer. Furthermore, the use of NAC was found to have an impact on decreasing the need for axillary lymph node dissection in selected patients presenting initially with positive lymph nodes. This article will review the current practice and indications of NAC in breast cancer as well as some controversial issues regarding the surgical management of the breast and the axilla following neoadjuvant treatment.

Key words: breast cancer, neoadjuvant chemotherapy, breast conserving surgery, sentinel node, biological treatment

\section{Introduction}

The use and indications for neoadjuvant chemotherapy (NAC) have evolved immensely over the past few decades. Historically, patients were referred to NAC mainly in those cases deemed to be clinically inoperable. However, it was soon observed that following primary medical treatment the majority of patients could be operated due to shrinkage of tumor burden (1). In the following years several studies have shown that in some patients with large tumors treatment allowed breast conserving surgery (BCS), avoiding the need for mastectomy (1-3). Although it was not found that initial medical treatment improves overall survival compared to surgery first, it became the standard of care for locally advanced breast cancer with the advantages of allowing assessment of treatment effectiveness as well as improving local control and chance for breast conserving surgery. Recent studies have shown that NAC may also deescalate surgery of the axilla in selected cases (4).

As clinical experience with NAC has increased along with the introduction of novel medications and better understanding of tumor biology, the indications for its use have become more common also in some subtypes of early cancer as the degree of response to treatment may dictate the need for additional therapy. Since it is a matter of great debate whether surgical paradigms used for primary surgery may also be applied following NAC, several important clinical studies have been recently carried out and other ongoing trials may solve these issues.

This article will review the current practice and indications for NAC in breast cancer and the surgical management including some controversial issues regarding the surgical treatment of the breast and the axilla following neoadjuvant treatment.

\section{Management of the Breast following NAC}

Early trails have shown that initial chemotherapy-based treatments provided before surgery have allowed BCS in about on fourth of the patients requiring mastectomy at presentation (1-3). More recent studies have shown that these rates may be dependent on the biology of the tumor which may be as high as $48 \%$ in patients with triple negative or HER-2 positive disease, but only $16 \%$ in hormone-receptor (HR)-positive/HER-2-negative invasive lobular cancer $(5,6)$. Similarly, a meta-analysis from 10 randomized studies with over 4700 patients which were randomly assigned to NAC or to surgery first, have shown a significant difference in the BCS rates $(65 \%$ for NAC compared to $49 \%$ for patients referred to surgery first, $\mathrm{p}<0.0001$ ) 
(6). Nevertheless, despite the increase in complete pathological response (pCR) rates in recent years, this observation was not translated to further increase in BCS rates. For example, in the CALGB 40603 trial, one third of patients assigned to mastectomy after NAC were found to have complete pathological response and thus could have been spared from mastectomy and managed by BCS (5). One reason for this finding is the inability to accurately evaluate the extent of viable disease following medical treatment. This dilemma is very common when dealing with patients with extensive suspicious microcalcifications for example. Since there is no strong data to show the relationship between changes in calcifications and response to treatment, excision of all suspicious calcifications is the common recommended practice resulting in many unnecessary mastectomies (7). In a recent study from a single institution $48 \%$ of patients $(n=600)$ presenting with large tumors, underwent successful BCS following NAC (8). Factors associated with high success rates were triple negative or HER-2 positive biology, complete pathological response, node negative disease and lack of pre-treatment diffuse mammographic microcalcifications.

A common and wrong reason for avoiding BCS in many patients is the belief that the entire volume of the initial disease must be resected to achieve safe oncological outcome. This misconception however has been disproved in many studies. The Early Breast Trialists' Collaborative Group conducted a meta-analysis of over 4700 patients that were enrolled to studies between the years 1983 and 2002 and treated with BCS and either adjuvant or neoadjuvant therapy (9). There were no differences in overall survival rates among the two groups and the local recurrence rate was only $3.2 \%$ higher in the NAC group. In another study, Boughey et al demonstrated that NAC decreased by half the volume of breast excised compared to similar patients undergoing initial surgery. There were no differences in re-excision rates or local recurrence at 3 years of follow-up (10).

The degree of response to NAC is a strong predictor for success of BCS and local control. Long term local control was $93 \%$ in all patients achieving pCR irrespective of tumor biology (11). In contrast, failure to achieve pCR was associated with higher local recurrence rates in HR-negative cancers, but not in HR-positive cancers (11). In a more recent meta-analysis derived from 9 studies, the 10year local recurrence rate was $6.5 \%$ and again HR-negative disease, node positive disease and lack of pCR were all associated with higher local recurrence rates (12).

Another issue of concern is the margin size needed to achieve low recurrence rates. When primary surgery is undertaken, no ink on tumor is widely accepted and has become the common practice in most centers treating breast cancer. In the setting of NAC there is a concern that heavy load of scattered viable foci of cancer may be untreated, thus larger margins are needed to be removed to provide secure surgery with low recurrences. This concern was not proved to be correct in numerous well conducted studies. In both the NSABP B18 and B27 trials, clear margins were defined as no tumor on ink and the local recurrences were low and comparable with those reported for primary surgery $(2,13)$. Similarly, Choi et al reported no differences at 5 years in local recurrence rates or overall survival between close margins or above $2 \mathrm{~mm}$ in patients undergoing NAC therapy (14).

Taken together, these results provide sound data for the use of BCS following NAC therapy. The indications for BCS after NAC do not differ from those of primary surgery of the breast in terms of need to achieve negative margins and satisfactory cosmetic outcome. BCS should be contraindicated when these factors cannot be achieved and may include diffuse microcalcifications and multicentric disease. In addition, there is no data to support BCS following NAC treatment for inflammatory breast cancer. The concern from rapid recurrence is so high that at this point inflammatory breast cancer is considered a contraindication for BCS even in the setting of complete clinical response (cCR).

From a practical point of view, some 
measures are advisable to provide safe surgery of the breast following NAC. First, all suspicious tumors should be biopsied and clipped upon diagnosis. This may ensure which lesions must be subsequently removed and allow identification of the tumor region in cases of cCR. Mammography and US should be performed prior to NAC and thereafter before surgery. Many also advocate routine use of MRI but this is a matter of debate. Another important point is that the whole course of NAC should be given prior to surgery since this action may determine those patients with pCR. This point is cardinal since additional treatment may differ between patients with $\mathrm{pCR}$ to those with partial response. For example, in the KATHERINE study it was shown that among patients with HER2positive early breast cancer who had residual invasive disease after completion of NAC, the risk of recurrence of invasive breast cancer or death was $50 \%$ lower with adjuvant T-DM1 than with trastuzumab alone (15). Thus, even if good response enabling BCS is possible during the course, it is paramount to continue the full course and only then commence with surgery.

For patients requiring mastectomy following NAC, immediate reconstruction is an acceptable approach of treatment. Immediate reconstruction is associated with less distress to the patient and better psychological well-being. However, post-mastectomy radiotherapy (PMRT) may be needed in many patients to improve locoregional disease control, and the integration of these treatments together remains challenging (16). PMRT is associated with significantly increased rates of complications and decreased patient satisfaction. The Mastectomy Reconstruction Outcome Consortium (MROC) reported that the risk of complications was 2.6 higher in patients with implant-based reconstruction compared to autologous reconstruction and the risk of reconstruction failure was $19 \%$ and $5 \%$, respectively (17). Nevertheless, not all women are eligible for autologous reconstruction and some patients and surgeons prefer implant-based reconstruction which is less technically demanding, associated with shorter operative time and hospital stay and allows greater flexibility with the reconstructed breast size. The type and timing of reconstruction has not been clearly defined and the benefit and trade-offs of each approach should be discussed with the patients.

\section{Management of the Axilla following NAC}

Historically, all NAC-treated patients underwent axillary lymph node dissection (ALND) regardless of the initial nodal status. Early studies have shown that the incidence of nodal metastases decreased from $57 \%$ to $41 \%$ in patients with locally advanced breast cancer treated with NAC (2). The practice of mandatory ALND in these patients for many years resulted from the notion that most patients with locally advanced cancers harbor nodal metastases and from doubts about the accuracy of sentinel lymph node biopsy (SLNB) in patients with clinically lymph node-negative disease in the setting of NAC and locally advanced disease. The main concerns were that fibrosis of lymphatic channels after NAC and non-uniform response of lymph nodes to treatment may result in unacceptable high false-negative rates. This however was proved to be incorrect in numerous studies. In one meta-analysis involving over 6000 women with clinically lymph node-negative disease that underwent NAC, the identification rates were $90-96 \%$ and the false negative rates were $6-12 \%$, comparable with the rates seen in up-front surgery $(18,19)$. These findings were also observed in the prospective GANEA 2 study. In this study the identification rate was $98 \%$ and nodal relapse was only $0.2 \%$ of patients with pathologically negative SLN at a median follow-up period of 4 years (20). Following these and other studies defining the accuracy of SLNB after NAC in patients presenting with $\mathrm{cN} 0$, the practice of performing SLNB after NAC has been widely adopted. In those patients that at least one of the SLNS is found positive, completion ALND is performed as there is no strong data to avoid this practice, and implementation of the 
Z0011 study cannot be justified.

In patients presenting with positive nodes before NAC, mandatory ALND was performed until very recently regardless of clinical response. Newer studies have shown very high nodal pCR rates in some subgroups of patients, suggesting that ALND may be over-treatment in many patients and that the role of SLNB in this setting should be examined. Indeed, this question has been the subject of investigation in four unrelated prospective studies (21-24). The identification rates of SLNs in these studies were somewhat lower than those observed for initial $\mathrm{cN} 0$ patients, ranging from $79 \%$ to $93 \%$. In all studies the overall false negative rates exceeded the accepted $10 \%$ threshold, but when two or three SLNs were harvested, the rates decreased below $10 \%$. In a meta-analysis including nearly 2,000 patients, Tee at all observed that false negative rates dropped from $19 \%$ to $11 \%$ when dual tracers were used, and that the false negative rates decreased from $20 \%$ with one node to $12 \%$ with two nodes and down to $4 \%$ with three or more nodes. At present the data regarding nodal relapse is scarce, but in one study including 70 patients that were diagnosed with node-positive disease before NAC and underwent negative SLNB without ALND following treatment, there were no nodal relapses at a median of 5 year follow-up. Thus, at present, in patients with initial node-positive disease showing clinical and radiological response, retrieval of 3 or more negative SLNs with the use of dual tracers may omit the need for ALND. Some will also argue that 2 negative SLNs may also be enough. This may be especially true in subtypes of cancer that have high pCR rates such as HER2-positive and triple-negative disease, with the highest rates in patients with HR-negative/HER2-positive. However, this issue was not validated yet.

Preoperative MRI or ultrasound examinations were not found to decrease the false negative rates of SLNB in this group of patients $(23,25)$. The role of clipping the diseased node at the time of initial biopsy and removing this node under wire localization following NAC is a matter of debate (21). This procedure termed targeted axillary dissection (TAG) has been strongly advocated by some surgeons as it may reduce the false negative rate to less than $7 \%$ in most studies, and in one study the rate was as low as $1.4 \%(21,26)$. In the latter study, the false negative rate of SLNB without a clipped node was $10.1 \%$, suggesting that TAG should be utilized. Nevertheless, in this study that included 120 patients, improper SLNB technique was utilized in $40 \%$ of patients using only a single tracer and the mean number of nodes removed was less than 3, putting the real role of TAG in question. Other studies have also questioned its utility as it was shown that actual retrieval rates of the clipped node may be low as $63 \%$ and in $23 \%$ of cases the clipped node is not an SLN. Therefore, the role of TAG at present is unclear although it may allow avoidance of ALND in cases that less than 3 SLNs are detected.

Metastasis found in any of the lymph nodes removed is at present an indication for completion ALND. This is clear for macrometastases but is also indicated for micrometastases. Unlike in the setting of up-front surgery where the risk of additional involved non SLNs in micrometastatic disease is $13 \%$, it was found that the risk of additional involved non SLNs following NAC is more than $60 \%$, similar to rates found in macrometastases (27). Residual micrometastases following NAC are associated with poorer prognosis and may be indicative for the need of additional systemic therapy.

\section{Future Directions}

We have evidenced a significant shift in the paradigm of surgical management of both the breast and the axilla following NAC in recent years. There are ongoing trials and studies that will examine whether further de-escalation may be safely used. For example, one interest is in the avoidance of any breast surgery in patients that pCR can be accurately determined by imaging and multiple core biopsies. This may be especially applicable for 
patients that show high rates of $\mathrm{pCR}$ such as HER2-positive and triple-negative patients. At present, there is insufficient data regarding the accuracy of multiple core biopsies. Although the false negative rate of core biopsies in determining pCR was $5 \%$ in one study, in other larger studies the rates ranged from $18 \%$ to $37 \%(28,29)$. Similarly, the reported false negative rate of MRI for pCR is nearly $20 \%$, higher than the rates that can be acceptable (25). Moreover, up to $9 \%$ of patients operated with pCR had local recurrence and the morbidity associated with BCS is very low, putting into question the need to consider avoiding this practice altogether. Other studies are examining additional indications that may avoid ALND. In one study, the Alliance A011202 trial, patients with positive SLNs after NAC are assigned to either completion ALND or radiotherapy. Here too, some clinicians raise the question of whether regional lymph node surgery is required altogether, since determination of treatment may be dictated by tumor biology and the benefit of survival is questionable. This is at present a thought only, but in the future it may well be that lymph node surgery will be left for salvage treatment only.

\section{Conflict of Interest}

No conflict of interest.

\section{Ethics Approval}

Ethical approval was not needed for this review article.

\section{References}

1. Bonadonna G, Veronesi U, Brambilla C, Ferrari L, Luini A, Greco M, et al Primary chemotherapy to avoid mastectomy in tumors with diameters of three centimeters or more. J Natl Cancer Inst. 1990;82(19):1539-45.

2. Fisher B, Brown A, Mamounas E, Wieand S, Robidoux A, Margolese RG, et al. Effect of preoperative chemotherapy on local-regional disease in women with operable breast cancer: findings from National Surgical Adjuvant Breast and Bowel Project B-18. J Clin Oncol. 1997;15(7):2483-93.

3. van der Hage JA, van de Velde CJ, Julien JP, Tubiana-Hulin M Vandervelden $C$, Duchateau $L$ et al. Preoperative chemotherapy in primary operable breast cancer: results from the European Organization for Research and Treatment of Cancer trial 10902. J Clin Oncol. 2001;19(22):4224-37.

4. Hunt KK, Yi M, Mittendorf EA, Guerrero C, Babiera GV Bedrosian I, et al.
Sentinel lymph node surgery after neoadjuvant chemo-therapy is accurate and reduces the need for axillary dissection in breast cancer patients. Ann Surg. 2009;250(4):558-66

5. Golshan M, Cirrincione CT, Sikov WM, Carey LA, Berry DA, Overmoyer B, et al. Impact of neoadjuvant therapy on eligibility for and frequency of breast conservation in stage II-III HER2-positive breast cancer: surgical results of CALGB 40601 (Alliance). Breast Cancer Res Treat. 2016;160(2):297-304.

6. Petruolo OA, Pilewskie M, Patil S, Barrio AV, Stempel M, Wen HV, et al. Standard Pathologic Features Can Be Used to Identify a Subset of Estrogen Receptor-Positive, HER2 Negative Patients Likely to Benefit from Neoadjuvant Chemotherapy. Ann Surg Oncol. 2017;24(9):2556-2562.

7. Criscitiello C, Golshan M, Barry WT, Viale G, Wong S, Santangelo M, et al. Impact of neoadjuvant chemotherapy and pathological complete response on eligibility for breast-conserving surgery in patients with early breast cancer: A meta-analysis. Eur J Cancer. 2018:97:1-6.

8. Petruolo 0, Sevilimedu V, Montagna G, Tiana Le 1, Morrow M, Barrio AV. How Often Does Modern Neoadjuvant Chemotherapy Downstage Patients to Breast-Conserving Surgery? Ann Surg Oncol. 2021;28(1):287-294. Epub 2020 Jun 8.

9. Early Breast Cancer Trialists' Collaborative Group (EBCTCG). Long-term outcomes for neoadjuvant versus adjuvant chemotherapy in early breast cancer: meta-analysis of individual patient data from ten randomised trials. Lancet Oncol. 2018;19(1):27-39. Epub 2017 Dec 11.

10. Boughey JC, Peintinger F, Meric-Bernstam F, Perry AC, Hunt KK, Babiera GV, et al. Impact of preoperative versus postoperative chemotherapy on the extent and number of surgical procedures in patients treated in randomized clinical trials for breast cancer. Ann Surg. 2006;244(3):464-70.

11. Swisher SK, Vila J, Tucker SL, Bedrosian I, Shaitelman SF, Litton JK, et al. Locoregional Control According to Breast Cancer Subtype and Response to Neoadjuvant Chemotherapy in Breast Cancer Patients Undergoing Breastconserving Therapy. Ann Surg Oncol. 2016;23(3):749-56.

12. Cortazar $\mathrm{P}$, Zhang L, Untch M, Mehta K, Costantino JP, Wolmark N, et al. Pathological complete response and long-term clinical benefit in breast cancer: the CTNeoBC pooled analysis. Lancet. 2014;384(9938):164-72

13. Bear HD, Anderson S, Smith RE, Geyer Jr CE, Mamounas EP, Fisher B, et al. Sequential preoperative or postoperative docetaxel added to preoperative doxorubicin plus cyclophosphamide for operable breast cancer: National Surgical Adjuvant Breast and Bowel Project Protocol B-27. J Clin Oncol. 2006;24(13):2019-27

14. Choi J, Laws A, Hu J, Barry W, Golshan M, King T. Margins in BreastConserving Surgery After Neoadjuvant Therapy. Ann Surg Oncol. 2018;25(12):3541-3547

15. von Minckwitz G, Huang CS, Mano MS, Loibl S, Mamounas EP, Untch M, et al. Trastuzumab Emtansine for Residual Invasive HER2-Positive Breast Cancer. N Engl J Med. 2019;380(7):617-628. Epub 2018 Dec 5.

16. Shumway DA, Momoh AO, Sabel MS, Jagsi R. Integration of Breast Reconstruction and Postmastectomy Radiotherapy. J Clin Oncol. 2020; 38(20):2329-2340.

17. Jagsi R, Momoh AO, Qi J, Hamill JB, Billig J, Kim HM, et al. Impact of Radiotherapy on Complications and Patient-Reported Outcomes After Breast Reconstruction. J Natl Cancer Inst. 2018;110(2):157-165.

18. Kelly AM, Dwamena B, Cronin P, Carlos RC. Breast cancer sentinel node identification and classification after neoadjuvant chemo-therapysystematic review and meta analysis. Acad Radiol. 2009; 16(5):551-63.

19. van Deurzen $\mathrm{CH}$, Vriens $\mathrm{BE}$, Tjan-Heijnen $\mathrm{VC}$, van der Wall $\mathrm{E}$, Albregts $\mathrm{M}$, Richard van Hilligersberg, et al. Accuracy of sentinel node biopsy after neoadjuvant chemotherapy in breast cancer patients: a systematic review. Eur J Cancer. 2009; 45(18):3124-30.

20. Hunt KK, Yi M, Mittendorf EA, Guerrero C, Babiera GV, Bedrosian I, et al. Sentinel lymph node surgery after neoadjuvant chemotherapy is accurate and reduces the need for axillary dissection in breast cancer patients. Ann Surg. 2009; 250(4):558-66

21. Boughey JC, Suman VJ, Mittendorf EA, Ahrendt GM, Wilke LG, Taback B, et al. Sentinel lymph node surgery after neoadjuvant chemotherapy in patients with node-positive breast cancer: the ACOSOG Z1071 (Alliance) clinical trial. JAMA. 2013;310(14):1455-61.

22. Kuehn T, Bauerfeind I, Fehm T, Fleige B, Hausschild M, Helms G, et al. 
Sentinel-lymph-node biopsy in patients with breast cancer before and after neoadjuvant chemotherapy (SENTINA): a prospective, multicentre cohort study. Lancet Oncol. 2013;14(7):609-18.

23. Boileau JF, Poirier B, Basik M, Holloway CMB, Gaboury L, Sideris L, et al. Sentinel node biopsy after neoadjuvant chemotherapy in biopsy-proven node-positive breast cancer: the SN FNAC study. J Clin Oncol. 2015;33(3): 258-64. Epub 2014 Dec 1.

24. Classe JM, Loaec C, Gimbergues P, Alran S, Tunon de Lara C, Dupre PF, et al. Sentinel lymph node biopsy without axillary lymphadenectomy after neoadjuvant chemotherapy is accurate and safe for selected patients: the GANEA 2 study. Breast Cancer Res Treat. 2019;173(2):343-352.

25. Weber JJ, Jochelson MS, Eaton A, Zabor EC, Barrio AV, Gemignani ML, et al. MRI and Prediction of Pathologic Complete Response in the Breast and Axilla after Neoadjuvant Chemotherapy for Breast Cancer. J Am Coll Surg. 2017;225(6):740-746

26. Caudle AS, Yang WT, Krishnamurthy S, Mittendorf EA, Black DM, Gilcrease MZ, et al. Improved Axillary Evaluation Following Neoadjuvant Therapy for
Patients With Node-Positive Breast Cancer Using Selective Evaluation of Clipped Nodes: Implementation of Targeted Axillary Dissection. J Clin Oncol. 2016;34(10):1072-8

27. Moo TA, Edelweiss M, Hajiyeva S, Stempel M, Raiss M, Zabor EC, et al. Is Low-Volume Disease in the Sentinel Node After Neoadjuvant Chemotherapy an Indication for Axillary Dissection? Ann Surg Oncol. 2018;25(6): 1488-1494.

28. Kuerer HM, Rauch GM, Krishnamurthy S, Adrada BE, Caudle AS, DeSnyder SM, et al. A Clinical Feasibility Trial for Identification of Exceptional Responders in Whom Breast Cancer Surgery Can Be Eliminated Following Neoadjuvant Systemic Therapy. Ann Surg. 2018;267(5):946-951.

29. van Loevezijn AA, van der Noordaa MEM, van Werkhoven ED, Loo CE, Winter-Warnars GAO, Wiersma $T$, et al. Minimally Invasive Complete Response Assessment of the Breast After Neoadjuvant Systemic Therapy for Early Breast Cancer (MICRA trial): Interim Analysis of a Multicenter Observational Cohort Study. Ann Surg Oncol. 2020 Dec 2. Online ahead of print. 